\title{
STRATEGI PENGELOLAAN PERIKANAN TANGKAP DI KAWASAN KONSERVASI PERAIRAN DAERAH (KKPD) LINGGA DI KABUPATEN LINGGA
}

\author{
Capture Fisheries Management Strategy in Regional Marine Protected Area (KKPD) in Lingga \\ District \\ Oleh: \\ Gogo Kamargoํㅜ, Domu Simbolon², Mustaruddin² \\ ${ }^{1}$ Mahasiswa Sekolah Pascasarjana Program Studi Teknologi Perikanan Laut, IPB \\ 2 Staf Pengajar Departemen PSP-FPIK-IPB \\ Korespondensi:gogodive9@gmail.com
}

\begin{abstract}
ABSTRAK
Kawasan Konservasi Perairan Daerah Lingga telah ditetapkan berdasarkan Surat Keputusan (SK) Bupati Kabupaten Lingga dengan No.280/KPTS/X/2014 seluas kurang lebih 385. 467,5 Ha, diberi nama KKPD Datok Bandar.Tujuan dari penelitian ini adalah menyusun strategi Pengelolaan Perikanan tangkap di KKPD Lingga. Rekomendasi strategi pengelolaan Perikanan tangkap ; 1) Peningkatan kesadaran masyarakat pesisir terhadap kelestarian lingkungannya. 2) Optimalisasi produktivitas perikanan tangkap skala kecil melalui peningkatan kwalitas SDM nelayan. 3) Penegakkan hukum secara tegas dan peningkatan sistem pengawasan pemanfaatan sumberdaya ikan berbasis masyarakat, termasuk peningkatan kwalitas SDM pengawas. 4) Pengembangan infrastruktur perikanan tangkap, termasuk sistem logistik penyediaan BBM. 5) Peningkatan kerjasama usaha penangkapan ikan melalui program kemitraan, untuk menjamin keberlanjutan biayaya operasional, dan pengembangan investasi usaha. 6) Pengembangan nilai tambah hasil perikanan tangkap untuk mensejahterakan pendapatan nelayan.
\end{abstract}

Kata kunci : Kawasan Konservasi Perairan Daerah (KKPD), KKPD Lingga, Perikanan Tangkap.

\begin{abstract}
Regional Marine Protected Area of Lingga Regency has been established based on the Lingga District Regent Decree (SK) with No.280 / KPTS / X / 2014 covering an area of approximately 385. 467.5 Ha. named KKPD Datok Bandar. The objectives of this study is develop a capture fisheries management strategy at the KKPD of Lingga. Recommended strategies for managing capture fisheries; 1) Increasing awareness of coastal communities towards environmental sustainability. 2) Optimizing the productivity of small-scale capture fisheries through improving the quality of fishermen's human resources. 3) Strict law enforcement and improvement of community based fish resource utilization monitoring systems, including improving the quality of HR supervisors. 4) Development of capture fisheries infrastructure, including fuel supply logistics systems. 5) Increased cooperation in fishing business through partnership programs, to ensure the sustainability of operational costs, and the development of business investment. 6) Development of value-added capture fisheries for the welfare of fishermen's income.
\end{abstract}

Keywords: Regional Marine Protected Area, KKPD of Lingga, Capture Fisheries. . 


\section{PENDAHULUAN}

Kawasan Konservasi di Wilayah Pesisir dan Pulau-Pulau Kecil menurut UU No.27/2007 yang telah direvisi menjadi UU No.1/2014 merupakan kawasan pesisir dan pulau-pulau kecil dengan ciri khas tertentu yang dilindungi. Peraturan Pemerintah No. 60 Tahun 2007 menetetapkan Kawasan Konservasi Perairan (KKP) sebagai kawasan perairan yang dilindungi, dikelola dengan sistem zonasi. Kawasan Konservasi Perairan Daerah (KKPD) Kabupaten Lingga telah ditetapkan berdasarkan Surat Keputusan (SK) Bupati Kabupaten Lingga dengan No.280/KPTS/X/2014 seluas kurang lebih 385.467,5 Ha, diberi nama KKPD Datok Bandar.

Upaya yang dilakukan pemerintah adalah mengembangkan kawasan konservasi perairan karena memberikan asas manfaat dan keadilan bagi masyarakat untuk memanfaatkan sumber daya ikan melalui kegiatan penangkapan di zona perikanan berkelanjutan dalam kawasan konservasi perairan. Konservasi kawasan perairan memiliki makna yang kompleks dan kontribusi positif bagi kelestarian sumber daya alam serta kesejahteraan masyarakat yang berkelanjutan (Supriharyono 2007). Konsep perikanan berkelanjutan mengharuskan adanya keseimbangan antara aspek ekologi, ekonomi dan sosial. Namun permasalahan yang timbul tidak seberat apa yang dihadapi pada saat sekarang, dimana baik konflik sosial yang timbul akibat kompetisi besar-besaran dalam memperebutkan ikan yang menjadi tujuan penangkapan, ataupun kerusakan lingkungan serta punahnya beberapa spesies ikan yang diakibatkannya telah menunjukkan indikator yang sangat memprihatinkan bagi kelangsungan hidup bagi generasi mendatang (Purbayanto dan Mulyadi 1999).

Sumber daya ikan yang terdapat di Kawasan Konservasi Perairan Daerah Lingga berpotensi mendapatkan tekanan dari berbagai kegiatan penangkapan ikan yang belum berwawasan lingkungan. Kegiatan-kegiatan tersebut diantaranya akibat pemanfaatan sumber daya ikan yang belum optimal dan belum memperhatikan penerapan kaidah pengelolaan perikanan berkelanjutan. Untuk itu, perlu dilakukan pengkajian mengenai "Strategi Pengelolaan Perikanan Tangkap di Kawasan Konservasi Perairan Daerah Lingga, Kabupaten Lingga".

\section{METODOLOGI PENELITIAN}

Penelitian ini dilaksanakan pada bulan Mei - November 2017, dengan waktu pengambilan data mulai dari bulan Juni 2017. Penelitian ini dilaksanakan di Kawasan Konservasi Perairan Daerah (KKPD) Lingga. Lokasi Penelitian di sajikan pada gambar 1.

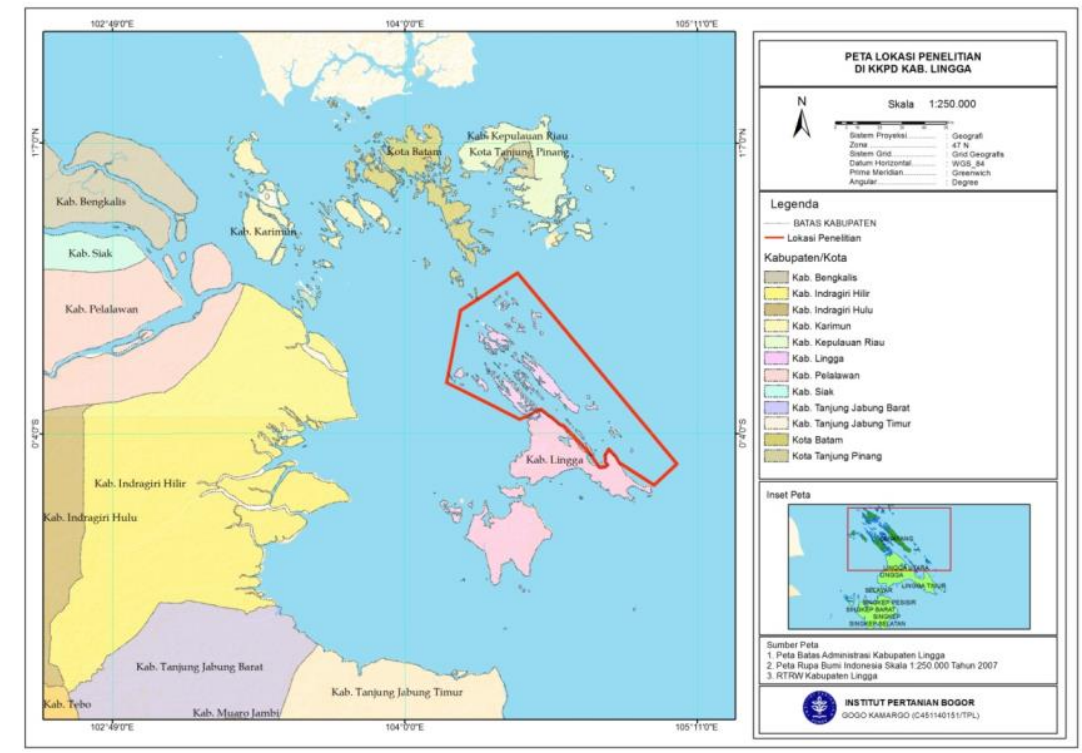

Gambar 1 Peta Lokasi Penelitian 
Data yang dikumpulkan pada penelitian ini adalah data primer dan sekunder. Adapun komponen yang dikumpulkan, jenis data perimer dan sekunder yang di kumpulkan terdiri dari empat klasifikasi yaitu data kondisi perairan, habitat wilayah pesisir, spot daerah penangkapan ikan dan profil unit penangkapan ikan. Kondisi perairan terkait dengan batimetri, pola arus, dan kualitas air, suhu permukaan laut (SPL), klorofil-a bersumber dari penelusuran pustaka, dokumen dari berbagai instansi terkait seperti DKP Kab. Lingga, DKP Provinsi. Kepri dan BPSPL Padang.

Kondisi habitat wilayah pesisir terkait dengan distribusi, kondisi dan luasan terumbu karang diperoleh dengan metode ground chek menggunakan alat snorkeling dan SCUBA teknik LIT atau Line Intercept Transect (UNEP, 1993), dengan ukuran transek $50 \mathrm{~m}$. Setiap biota yang dilewati transek dicatat menurut kategori dan taksonnya. Dari data tersebut akan diketahui persentase tutupan, keragaman jenis dan dominasi karang. Setiap stasiun diten $\neg$ tukan titik-titik pengambilan data sesuai hasil survei. Setiap titik dibagi dalam 2 kedalaman yaitu $3 \mathrm{~m}$ dan $10 \mathrm{~m}$. Padang lamun dan hutan mangrove diperoleh menggunakan teknik transek. Selain itu data sekunder terkait kondisi habitat wilayah pesisir KKPD Lingga juga diperoleh dari berbagai instansi terkait seperti DKP Lingga, DKP Provinsi, LIPI dan seterusnya.

Spot-spot penangkapan ikan sesuai dengan alat penangkapan ikan yang di operasikan di zona perikanan berkelanjutan, diperoleh melalui metode survei. Spot-spot penangkpan ikan dikelompokkan melalui pemetaan partisipatif nelayan, sistem informasi geografis (SIG) melalui overlay dengan peta zonasi KKPD Lingga. Data sekunder diperoleh dari studi pustaka dan penelusuran dokumen pada instansi terkait, yaitu DKP Kabupaten Lingga, DKP Provinsi Kepri, BPSPL Padang dan seterusnya.

Data profi nelayan, jenis alat tangkap, jumlah trip hari operasi setiap trip, hasil tangkapan, hasil tangkapan samping (by-catch), perspektif nelayan mengenai program konservasi diperoleh melalui wawancara dan observasi/pengamatan lapangan dalam kegiatan experimental. Selain itu data sekunder jenis dan jumlah unit penangkapan ikan diperoleh dari BPS Lingga, Kabupaten Lingga, DKP Provinsi Kepri dan seterusnya.

Strategi pengelolaan perikanan tangkap berkelanjutan dianalisis dengan metode Strengths Weaknesses Opportunities Threats (SWOT)). Analisis SWOT adalah suatu cara untuk mengidentifikasi berbagai faktor secara sistematis dalam rangka merumuskan strategi. Analisis ini didasarkan pada logika dapat memaksimalkan kekuatan (strength) dan peluang (opportunities), namun secara bersamaan dapat meminimalkan kelemahan (weakness) dan ancaman (threats) (Rangkuti 2000).

Analisis SWOT pada penelitian ini digunakan untuk menyusun strategi-strategi dalam pengelolaan perikanan tangkap berkelanjutan dengan memperhitungkan faktor internal yaitu kekuatan (strength) dan kelemahan (weaknesess) serta faktor eksternal yaitu peluang (opportunities) dan ancaman (threat). Analisis SWOT membandingkan antara faktor eksternal peluang (opportunities) dan ancaman (trhreats) dengan faktor internal kekuatan (strength) dan kelemahan (weaknesess). Proses yang harus dilakukan dalam pembuatan analisis $S W O T$ agar keputusan yang diperoleh lebih tepat perlu melalui berbagai tahapan sebagai berikut : tahap pengambilan data yaitu evaluasi faktor eksternal dan internal, tahap analisis yaitu pembuatan matriks internal eksternal dan matriks $S W O T$, dan tahap pengambilan keputusan. Menurut Marimin (2004), analisis sistem dapat diperoleh melalui survei, Pendapat Para ahli, diskusi, observasi lapangan.

Tahapan selanjutnya adalah membuat matriks lingkungan internal (IFAS/internal strategic factor summary) dan matriks lingkungan eksternal (EFAS/external strategic factors summary). Tahapannya, pertama menentukan faktor-faktor yang menjadi kekuatan dan kelemahan. Selanjutnya penentuan faktor-faktor yang menjadi peluang dan ancaman. Setelah itu, dibuat matriks SWOT yang menjelaskan berbagai alternatif yang mungkin untuk strategi pengelolaan. Menurut Rangkuti (2014), menyebutkan bahwa penyusunan matriks SWOT merupakan alat pencocokan yang penting untuk mengembangkan empat tipe strategi, dimana pencocokan memerlukan kecermatan Dalam matriks ini 
dapat menggambarkan secara jelas bagaimana peluang dan ancaman eksternal yang dihadapi dapat disesuaikan dengan kekuatan dan kelemahan yang dimiliki.

Tahapan penyususnan matrik IFAS dan matrik EFAS, serta analisis SWOT sebagai berikut :

Penyusunan Matrik Faktor Strategi Internal (IFAS) :

1. Menentukan faktor-faktor yang menjadi kekuatan dan kelemahan dalam pengelolaan Daerah Penangkapan Ikan (DPI) di Kawasan Konservasi Perairan Daerah Lingga secara wawancara dengan diskusi, pengamatan lapang dan penelaahan pustaka

2. Menentukan peringkat masing-masing faktor kekuatan dan kelemahan berdasarkan diskusi dengan stakeholder dan pakar, dengan skala 1-4 (pengaruh kecil-sedang-besar-sangat besar)

3. Memberikan bobot masing-masing faktor tersebut berdasarkan masukan dari stakeholder, dengan skala mulai dari 1,0 (paling penting) sampai 0,0 (tidak penting). Jumlah bobot dari seluruh faktor tidak boleh melebihi nilai 1.0

4. Menghitung nilai pengaruh masing-masing faktor dengan cara mengalikan nilai bobot dengan nilai peringkat untuk masing-masing faktor.

Penyusunan Matrik Faktor Strategi Eksternal (EFAS):

1. Menentukan faktor-faktor yang menjadi peluang dan ancaman dalam pengelolaan Daerah Penangkapan Ikan (DPI) di Kawasan Konservasi Perairan Daerah Lingga di Kabupaten Lingga secara kolaboratif dengan metode diskusi, pengamatan lapang dan penelaahan pustaka

2. Menentukan peringkat masing-masing faktor peluang dan ancaman berdasarkan pendapat stakeholder, dengan skala 1 - 4 (pengaruh kecil - sedang - besar - sangat besar).

3. Memberikan bobot masing-masing faktor tersebut berdasarkan masukan dari pihak pengelola KKPD Lingga, dengan skala mulai dari 1,0 (paling penting) sampai 0,0 (tidak penting). Jumlah bobot dari seluruh faktor tidak boleh melebihi nilai 1,0

4. Menghitung nilai pengaruh masing-masing faktor dengan cara mengalikan nilai bobot dengan nilai peringkat untuk masing-masing faktor.

Berdasarkan Matriks IFAS dan Matriks EFAS selanjutnya dibuat matriks SWOT. Berdasarkan matriks SWOT dapat menghasilkan empat set kemungkinan alternatif strategis pengelolaan Daerah Penangkapan Ikan (DPI) di Kawasan Konservasi Perairan Daerah Lingga di Kabupaten Lingga (Rangkuti, 2006) yaitu:

1) Strategi SO : menggunakan kekuatan untuk memanfaatkan peluang,

2) Strategi ST : menggunakan kekuatan untuk mengatasi ancaman,

3) Strategi WO : mengatasi kelemahan untuk memanfaatkan peluang, dan

4) Strategi WT : mengatasi kelemahan dan menghindari ancaman.

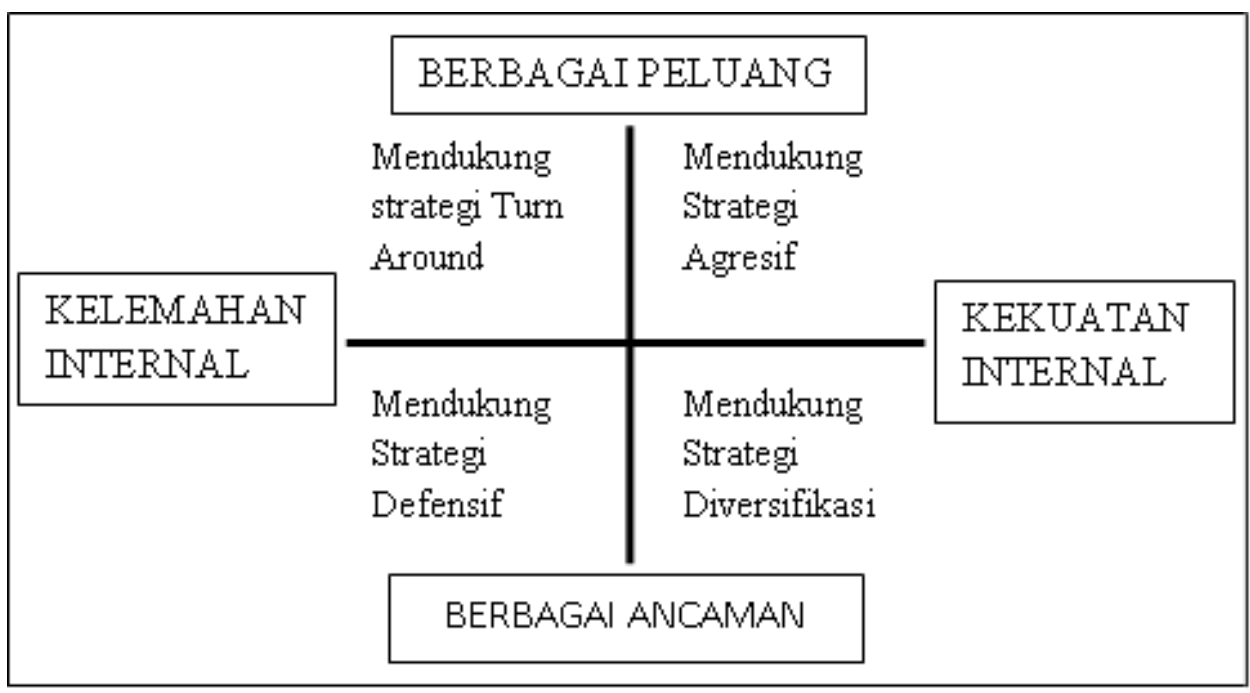

Gambar 2 Diagram Analisis SWOT 
Tabel 1 Matriks SWOT

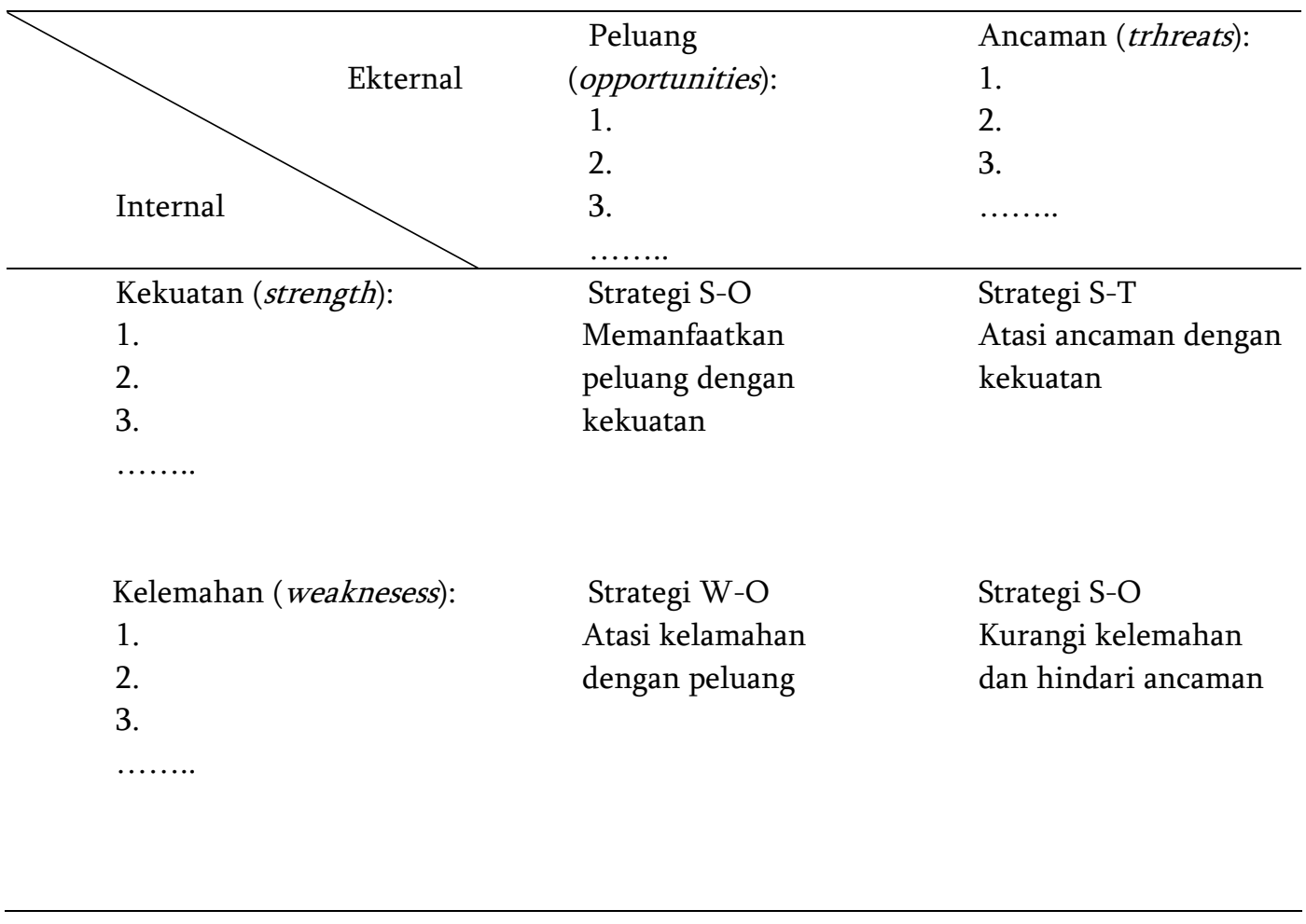

Menurut Simbolon (2017) tindakan strategis untuk mendukung sistem informasi daerah penangkapan ikan adalah pengaturan zonasi menurut jenis alat tangkap, penggunaan teknologi berwawasan lingkungan, dan pengendalian upaya penangkapan pada kondisi optimal.

\section{HASIL DAN PEMBAHASAN}

\section{Faktor internal dan Eksternal Pengelolaan Perikanan Tangkap}

Pengelolaan sektor perikanan tangkap di suatu daerah, secara umum dipengaruhi oleh lingkungan strategisnya, baik lingkungan internal maupun eksternal, yang dapat menentukan tingkat keberhasilan dalam upaya perencanaan dan implementasinya. Faktor internal dan eksternal secara sinergis akan menentukan kekuatan dan kelemahan kawasan terutama pemerintah daerah untuk tetap berada pada jalur kewenangannya dalam menyikapi permasalahan dan peluang yang ada maupun yang akan datang. Kondisi tersebut akan menempatkan eksistensi yang sangat baik bagi perencanaan pengembangan perikanan tangkap ke depan.

\section{Identifikasi dan Analisis Faktor Lingkungan Internal}

Lingkungan internal merupakan semua kondisi dan faktor yang berada di dalam batas wilayah administratif (yang mencakup sumber daya alam, sumber daya manusia, infrastruktur, kelembagaan dan sosial ekonomi) dan wewenang pemerintah daerah Kabupaten Lingga yang mungkin dapat berfungsi sebagai kekuatan yang dapat mendukung dan mendorong pemerintah daerah dalam mengemban misi dan mewujudkan visinya atau sebaliknya sebagai kelemahan yang dapat menghambat dalam mengemban misi dan mewujudkan visinya. Faktor-faktor lingkungan internal yang terdapat pada perikanan tangkap di KKPD Lingga di Kabupaten Lingga disajikan pada Tabel 2. 
Tabel 2 Faktor-faktor Lingkungan Internal pada Perikanan tangkap di KKPD Lingga

\begin{tabular}{|l|ll|}
\hline \multicolumn{1}{|c|}{ Kekuatan } & \multicolumn{1}{|c|}{ Kelemahan } \\
\hline \hline 1. Memiliki perairan laut dengan potensi & 1. $\begin{array}{l}\text { Pemanfaatan SDI di perairan KKPD } \\
\text { SDI yang besar dan beragam (pelagis } \\
\text { besar, pelagis kecil, demersal, dan ikan } \\
\text { karang) }\end{array}$ & 2. $\begin{array}{l}\text { Masih terbatasnya infrastruktur dasar } \\
\text { dan prasarana perikanan tangkap }\end{array}$ \\
$\begin{array}{l}\text { 2. Tersedia jumlah tenaga kerja yang cukup } \\
\text { 3. Lingkungan perairan lautnya mempunyai } \\
\text { tingkat kesuburan yang baik, sehingga } \\
\text { banyak terdapat daerah penangkapan } \\
\text { ikan (fishing ground) yang potensial }\end{array}$ & 3. $\begin{array}{l}\text { Kemampuan permodalan nelayan } \\
\text { setempat masih terbatas }\end{array}$ \\
4. Kondisi geografis yang strategis & Kasih rawan konflik antar nelayan di \\
\hline
\end{tabular}

Tabel 3 Penilaian Faktor-faktor Internal pada Perikanan tangkap di KKPD Lingga

\begin{tabular}{|l|l|l|r|r|}
\hline No. & \multicolumn{1}{|c|}{ Parameter } & Bobot & Skor & Jumlah \\
\hline A. & Kekuatan & & & \\
\hline 1. & $\begin{array}{l}\text { Memiliki potensi perairan laut dengan sumberdaya ikan } \\
\text { beragam (pelagis, demersal, dan ikan karang) }\end{array}$ & 4 & 0.20 & 0.8 \\
\hline 2. & Tersedia jumlah tenaga kerja yang cukup & 3 & 0.12 & 0.36 \\
\hline 3. & $\begin{array}{l}\text { Lingkungan perairan lautnya mempunyai tingkat kesuburan } \\
\text { yang baik, sehingga banyak terdapat daerah penangkapan } \\
\text { ikan yang potensial }\end{array}$ & 3 & 0.13 & 0.39 \\
\hline 4. & Kondisi geografis yang strategis & 4 & 0.15 & 0.6 \\
\hline B. & Kelemahan & & & 0.12 \\
\hline 1. & $\begin{array}{l}\text { Pemanfaatan SDI di KKPD di Kab Lingga belum optimal dan } \\
\text { merata }\end{array}$ & 2 & 0.12 \\
\hline 2. & $\begin{array}{l}\text { Masih terbatasnya infrastruktur dasar dan prasarana } \\
\text { perikanan tangkap }\end{array}$ & 2 & 0.05 & 0.1 \\
\hline 3. & Akses permodalan ke lembaga keuangan masih terbatas & 3 & 0.1 & 0.3 \\
\hline 4. & $\begin{array}{l}\text { Investasi di sub-sektor perikanan tangkap belum berkembang } \\
\text { baik }\end{array}$ & 3 & 0.13 & 0.39 \\
\hline & JUMLAH & & 1.00 & 3.18 \\
\hline
\end{tabular}

\section{Identifikasi dan Analisis Faktor Lingkungan Eksternal}

Lingkungan eksternal merupakan semua kondisi dan faktor yang berada diluar wilayah dan wewenang Pemerintah Kabupaten Lingga yang mungkin dapat dijadikan sebagai peluang dalam mengemban misi dan mewujudkan visi atau sebaliknya menjadi suatu ancaman. Lingkungan eksternal mencakup teknologi, pasar, konsumen, investor, donatur (dalam dan luar negeri) serta Kementerian Kelautan dan Perikanan. Faktor-faktor lingkungan eksternal yang terdapat pada perikanan tangkap di KKPD Lingga di Kabupaten Lingga disajikan pada Tabel 4. 
Tabel 4 Faktor-faktor Lingkungan Eksternal pada Perikanan Tangkap di KKPD Lingga

\begin{tabular}{|c|c|}
\hline Peluang & Ancaman \\
\hline $\begin{array}{l}\text { 1. Permintaan akan komoditi ikan yang } \\
\text { terus meningkat sejalan dengan } \\
\text { pertambahan penduduk dan kesadaran } \\
\text { pola hidup akan asupan makanan yang } \\
\text { sehat. } \\
\text { 2. Kebijakan penghentian izin usaha } \\
\text { penangkapan ikan oleh armada asing di } \\
\text { ZEE Indonesia. } \\
\text { 3. Dekat dengan pasar ikan internasional } \\
\text { 4. Diterapkannya "traceablility" pada } \\
\text { produk-produk perikanan ekspor. }\end{array}$ & $\begin{array}{l}\text { 1. Fluktuasi harga dan kelangkaan BBM } \\
\text { 2. Moda transportasi dan pengangkutan } \\
\text { yang masih terbatas dan mahal } \\
\text { 3. Adanya pencemaran dari limbah rumah } \\
\text { tangga dan industri, serta kegiatan di } \\
\text { wilayah pesisir yang tidak ramah } \\
\text { lingkungan } \\
\text { 4. Sarana telekomonikasi jaringan } \\
\text { Handphone masih terbatas }\end{array}$ \\
\hline
\end{tabular}

Tabel 5 Penilaian Faktor-faktor Eksternal Perikanan Tangkap di KKPD Lingga

\begin{tabular}{|c|c|c|c|c|}
\hline No. & Parameter & Skor & Bobot & Jumlah \\
\hline A. & Peluang & & & \\
\hline 1. & $\begin{array}{l}\text { Permintaan akan komoditi ikan yang terus meningkat sejalan } \\
\text { dengan pertambahan penduduk dan kesadaran pola hidup } \\
\text { akan asupan makanan yang sehat. }\end{array}$ & 3 & 0.13 & 0.39 \\
\hline 2. & $\begin{array}{l}\text { Kebijakan penghentian izin usaha penangkapan ikan oleh } \\
\text { armada asing di ZEE Indonesia. }\end{array}$ & 3 & 0.15 & 0.45 \\
\hline 3. & Dekat dengan pasar ikan internasional & 4 & 0.21 & 0.84 \\
\hline 4. & $\begin{array}{l}\text { Diterapkannya "traceablility" pada produk-produk perikanan } \\
\text { ekspor }\end{array}$ & 3 & 0.1 & 0.3 \\
\hline B. & Ancaman & & & \\
\hline 1. & Fluktuasi harga dan kelangkaan BBM & 2 & 0.17 & 0.34 \\
\hline 2. & $\begin{array}{l}\text { Moda transportasi dan pengangkutan yang masih terbatas } \\
\text { dan mahal }\end{array}$ & 2 & 0.09 & 0.18 \\
\hline 3. & $\begin{array}{l}\text { Adanya pencemaran dari limbah rumah tangga dan industri, } \\
\text { serta kegiatan di wilayah pesisir yang tidak ramah } \\
\text { lingkungan }\end{array}$ & 2 & 0.15 & 0.3 \\
\hline & JUMLAH & & 1.00 & 2.8 \\
\hline
\end{tabular}

\section{Strategi Pengelolaan Perikanan Tangkap di Kawasan Konservasi Perairan Daerah Lingga di}

\section{Kabupaten Lingga}

Setelah kondisi lingkungan strategis (kekuatan, kelemahan, peluang dan ancaman) sektor perikanan tangkap di KKPD Lingga di Kabupaten Lingga teridentifikasi, maka selanjutnya dilakukan perumusan strategi pengembangannya dengan menggunakan matriks atau analisis SWOT (strengthsweakness-opportunity-threats). Analisis ini didasarkan pada logika yang dapat memaksimalkan kekuatan (strengths) dan peluang (opportunity), namun secara bersamaan dapat mengatasi atau meminimalkan kelemahan (weakness) dan ancaman (threats). Rumusan strategi yang diperlukan untuk pengembangan perikanan tangkap di KKPD Lingga di Kabupaten Lingga hasil generating dari matriks SWOT dapat dilihat pada Tabel 6. 
Tabel 6 Matriks SWOT untuk Pengelolaan Perikanan Tangkap di KKPD lingga di Kabupaten Lingga.

\begin{tabular}{|c|c|c|}
\hline $\begin{array}{l}\text { FAKTOR } \\
\text { EKSTERNAL }\end{array}$ & $\begin{array}{l}\text { STRENGTHS(S) } \\
\text { 1. Memiliki perairan laut } \\
\text { dengan potensi SDI yang } \\
\text { besar dan beragam } \\
\text { (pelagis besar, pelagis } \\
\text { kecil, demersal, dan ikan } \\
\text { karang) } \\
\text { 2. Tersedia jumlah tenaga } \\
\text { kerja yang cukup } \\
\text { 3. Lingkungan perairan } \\
\text { lautnya mempunyai } \\
\text { tingkat kesuburan yang } \\
\text { baik, sehingga banyak } \\
\text { terdapat daerah } \\
\text { penangkapan ikan } \\
\text { (fishing ground) yang } \\
\text { potensial } \\
\text { Kondisi geografis yang } \\
\text { strategis }\end{array}$ & $\begin{array}{l}\text { WEAKNESSES }(\mathrm{W}) \\
\text { 1. Pemanfaatan SDI di } \\
\text { KKPD di Kab Lingga } \\
\text { belum optimal dan merata } \\
\text { 2. Masih terbatasnya } \\
\text { infrastruktur dasar dan } \\
\text { prasarana perikanan } \\
\text { tangkap } \\
\text { 3. Kemampuan permodalan } \\
\text { nelayan setempat masih } \\
\text { terbatas } \\
\text { 4. Masih rawan konflik antar } \\
\text { nelayan di KKPD Lingga }\end{array}$ \\
\hline $\begin{array}{ll}\text { OPPORTUNITIES }(\mathrm{O}) \\
\text { 1. } & \text { Permintaan akan } \\
\text { komoditi ikan yang } \\
\text { terus meningkat } \\
\text { 2. } \\
\text { Kebijakan } \\
\text { penghentian izin } \\
\text { usaha penangkapan } \\
\text { ikan oleh armada asing } \\
\text { di ZEE Indonesia. } \\
\text { 3. Dekat dengan pasar } \\
\text { ikan internasional } \\
\text { 4. Diterapkannya } \\
\text { "traceablility" pada } \\
\text { produk-produk } \\
\text { perikanan ekspor. }\end{array}$ & \begin{tabular}{l}
\multicolumn{1}{c}{ STRATEGI SO } \\
- \\
Pengembangan nilai lebih \\
hasil perikanan tangkap \\
yang mampu \\
memanfaatkan komoditas \\
SDI yang ada. \\
- Optimalisasi produktivitas \\
perikanan tangkap skala \\
kecil
\end{tabular} & 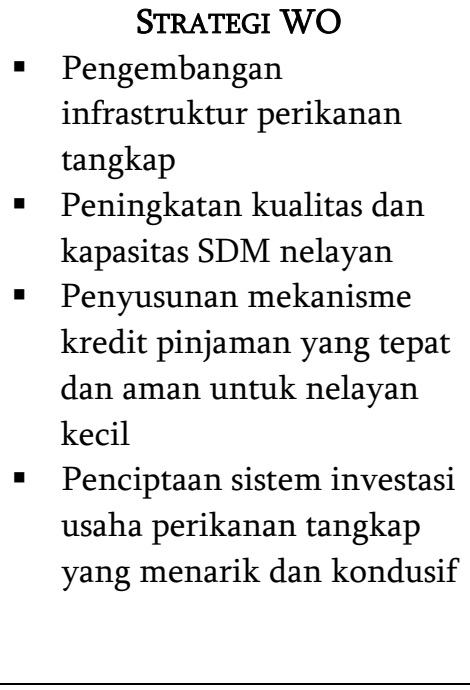 \\
\hline 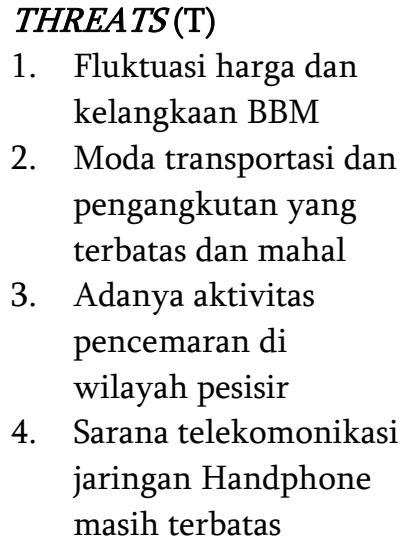 & 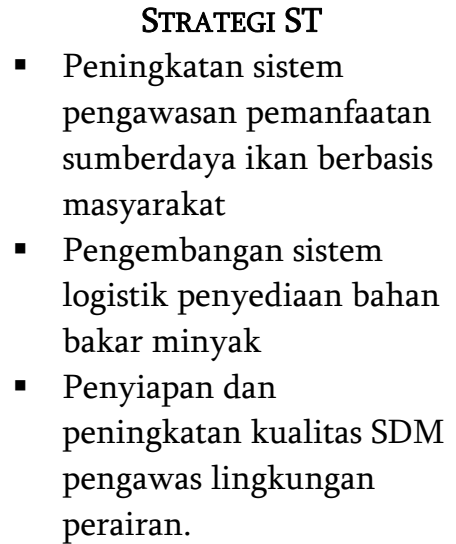 & \begin{tabular}{ll} 
& \multicolumn{1}{c}{ STRATEGI WT } \\
- & Peningkatan penegakan \\
hukum secara tegas \\
- & Peningkatan kerjasama \\
usaha penangkapan ikan \\
melalui program kemitraan \\
- & Peningkatan kesadaran \\
masyarakat pesisir terhadap \\
kelestarian lingkungannya.
\end{tabular} \\
\hline
\end{tabular}




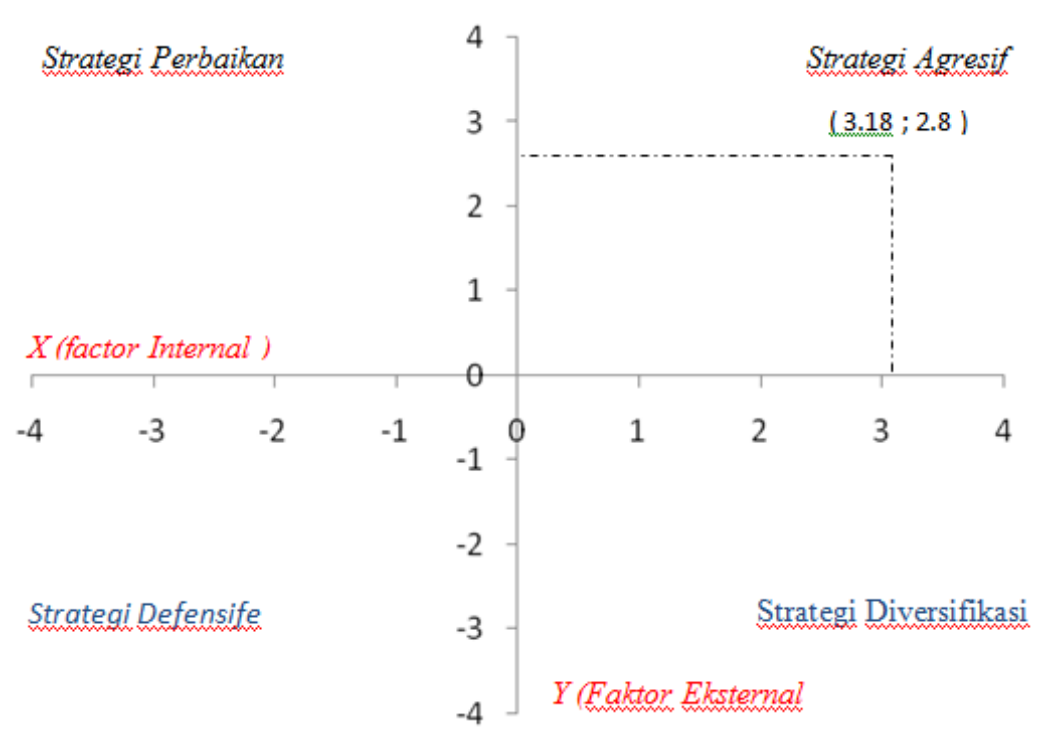

Gambar 3 Diagram Hasil Analisis SWOT

\section{KESIMPULAN}

1) Peningkatan kesadaran masyarakat pesisir terhadap kelestarian lingkungannya.

2) Optimalisasi produktivitas perikanan tangkap skala kecil melalui peningkatan kwalitas SDM nelayan

3) Penegakkan hukum secara tegas dan peningkatan sistem pengawasan pemanfaatan sumberdaya ikan berbasis masyarakat, termasuk peningkatan kwalitas SDM pengawas.

4) Pengembangan infrastruktur perikanan tangkap, termasuk sistem logistik penyediaan BBM

5) Peningkatan kerjasama usaha penangkapan ikan melalui program kemitraan, untuk menjamin keberlanjutan biayaya operasional, dan pengembangan investasi usaha.

6) Pengembangan nilai tambah hasil perikanan tangkap untuk mensejahterakan pendapatan nelayan.

\section{DAFTAR PUSTAKA}

[BPS] Badan Pusat Statistik Kabupaten Lingga. 2017. Senayan Dalam Angka Tahun 2017. Lingga (ID).

BPSPL Padang. 2014. Dokumen Rencana Zonasi Wilayah Pesisir Kabupaten Lingga

Bubun RL dan Mahmud A. 2015. Komposisi Hasil Tangkapan Pukat Cicin Hubungannya dengan Teknologi Penangkapan Ikan Ramah Lingkungan.Marine Fisheries. 6(2): 15-26

Coremap - CTI - LIPI. 2014. Monitoring Kesehatan Terumbu Karang dan Kesehatan Ekosistem Terkait di Kabupaten Lingga.

Darmono OP, FA Sondita dan S Martasuganda. 2016.Teknologi Penangkapan Baronang Ramah Lingkungan di Kepulauan Seribu (The Suistainable Technology Fisheries of Rabbit Fish in Seribu Islands).Jurnal Teknologi Perikanan dan Kelautan Vol. 7 No. 1.

DKP Lingga. 2015. Dokumen Rencana Pengelolaan Kawasan Konservasi Daerah Kabupaten Lingga

Marimin. 2004. Pengembalian Keputusan Kriteria Majemuk. Jakarta (ID) : Garasindo

Purbayanto A dan MS Baskoro. 1999. Tinjauan Singkat Tentang Pengembangan Teknologi Penangkapan Ikan Ramah Lingkungan. Proceeding of the Second Symposium on Agri-Bioche 98, 28-32p. 
Rangkuti F. 2000. Analisis SWOT, Teknik Membedah Kasus Bisnis. Reorientasi Konsep Perencanaan Strategis untuk Menghadapi Abad 21. Jakarta (ID): PT. Gramedia Pustaka Utama.

Rangkuti, F. 2014. Teknik Membedah Kasus Bisnis Analisi SWOT. Jakarta : PT Gramedia Pustaka.

Simbolon D. 2017. Daerah Penangkapan Ikan dalam Pengembangan Perikanan Tangkap Berkelanjutan.Bogor (ID).

Supriharyono. 2007. Konservasi Ekosistem Sumber daya Hayati di Wilayah Pesisir dan Laut Tropis. Yogyakarta (ID): Pustaka Pelajar.

Sutomo, A Purbayanto, D Simbolon, dan M Manan. 2011. Pemilihan Model Co-Management Pengelolaan Perikanan Tangkap.Jurnal Teknologi Perikanan dan Kelautan Vol. 2 No. 1 Hal 6170.

UNEP/AIMS. 1993. Monitoring Coral Reets for Global Change, Regional Seas. Reference, Methods for Marine Pollution Studies No.61 Kenya : UNEP

[LIPI] Lembaga Ilmu Pengetahuan Indonesia. 2011. Monitoring Kesehatan Terumbu Karang Kabupaten Lingga. Jakarta (ID). 